\title{
Surveying and Mapping: Panacea to the Challenges of Sustainable Development and National Security in Nigeria
}

\author{
Adegboyega Emmanuel Rotimi \\ Department of Geography and Planning Science, Ekiti State University, Nigeria
}

Received October 20, 2019; Revised December 16, 2019; Accepted December 25, 2019

Copyright $\odot 2020$ by authors, all rights reserved. Authors agree that this article remains permanently open access under the terms of the Creative Commons Attribution License 4.0 International License

\begin{abstract}
Sustainable development and national security have received a great deal of attention from a number of developed and developing countries of the world including Nigeria. Various efforts are put in place to ensure sustainable development and national security through reliable information on the location, extent and quality of the development put in place (serve as basic requirements for land use, land use planning and national security) in Nigeria. It is the responsibility of the Federal and State governments respectively to deliver political goods such as health, education, economic opportunity, good governance, fundamental infrastructure (transport and communication) and security. Both primary and secondary sources of data were used for the research to know why people build houses and other structures along river banks, within the areas liable to flooding, as well as under electricity high tension. It draws attention to the challenges facing sustainable development and security in Nigeria. The paper discusses the ignorance of people towards the existing rules and standards provided through Land Information System (LIS) on land such as setbacks (offsets) and reveals that most governments (federal, states, and local) in the course of carrying out their responsibilities waste resources due to non-compliance to the available guide map (land information provided).This made over $65 \%$ of developments to be under security threats and cause loss of lives and properties in Nigeria. The paper concluded that awareness and education should be given to the public and recommended that some states should take their priorities right by carrying out digital mapping in their states and ensuring compliance with the land information management (LIM) for national security in Nigeria.
\end{abstract}

Keywords Compliance, National Security, Setbacks, Sustainable Development, Surveying and Mapping

\section{Introduction}

Any meaningful development cannot stand aloof but must be put on somewhere else that is, on land. Land is the solid part of the earth surface, an ultimate natural resource, without which life on earth cannot be sustained. Surveying and mapping are ubiquitous, and they are the bedrocks of any meaningful development [7]. Therefore, developments such as building, roads, transport and communication put on land must be properly guided and managed for the sake of sustainability [10].

It is important to have the knowledge about site investigation, land use, land use planning and land use change in any nation so as to overcome the challenges of haphazard, uncontrolled development, deteriorating environmental qualities, destruction of prime agricultural lands and loss of wildlife habitats that constitute threat to the nation's security other than Boko Haram's insurgence in Nigeria [2]. Land information system (LIS) is needed to actualize the processes involved in managing the use of land and the development on land in a sustainable way. This development involves all activities associated with the management of land such as tenure, rent, value and use on land [16]. As part of pre-planning processes, the choice of site, its investigation, analysis, monitoring and treatment relating to land requires initial work to avoid disaster (life-threat) in our environment.

Nigeria as one of the developing countries needs availability of relevant and current information about her environment and its changes over time. Any meaningful development on land should take cognizance of the developmental control so as not to wreak havoc to the development and to ensure safety through the land information system which can only come through survey and mapping. [15] in his discourse pointed out the initial steps of risk management process following the recognition that disaster has occurred, and that human 
health and safety of the environment could be affected negatively and as such, the professionals of risk management could come to safe the situation. Therefore, prior to any development, the professionals should collect, possibly with the stakeholders, available existing information associated to such development in Nigeria.

\section{Aim and Objectives of the Study}

The aim of the study is to explore the potentials of Surveying and Mapping as panacea to the challenges of sustainable development and national security in Nigeria.

The specific objectives of this study are to:

i) use surveying and mapping as a tool to implement necessary Land Information for national development and security challenges,

ii) inform the populace and ensure compliance with environmental laws and developmental controls in Nigeria. iii) examine the havoc that may ensue for non-compliant to environmental laws in Nigeria and, recommend the possible remedial measures to alleviate the problems in the study area.

\section{Materials and Methods}

\subsection{The Study Area}

Nigeria is in West Africa, and it is located between Latitude $2^{0} \mathrm{~N}$ and $14^{0} \mathrm{~N}$ of the Equator and between longitude $3^{0} \mathrm{E}$ and $15^{0} \mathrm{E}$ of Greenwich Meridian. It is bordered in the south by Bight of Benin on the Atlantic Ocean, in the west by the Republic of Benin, in the east by Cameroun and Chad and in the north by Niger Republic. It comprised 36 states and the FCT, Abuja (see Figure. 1)

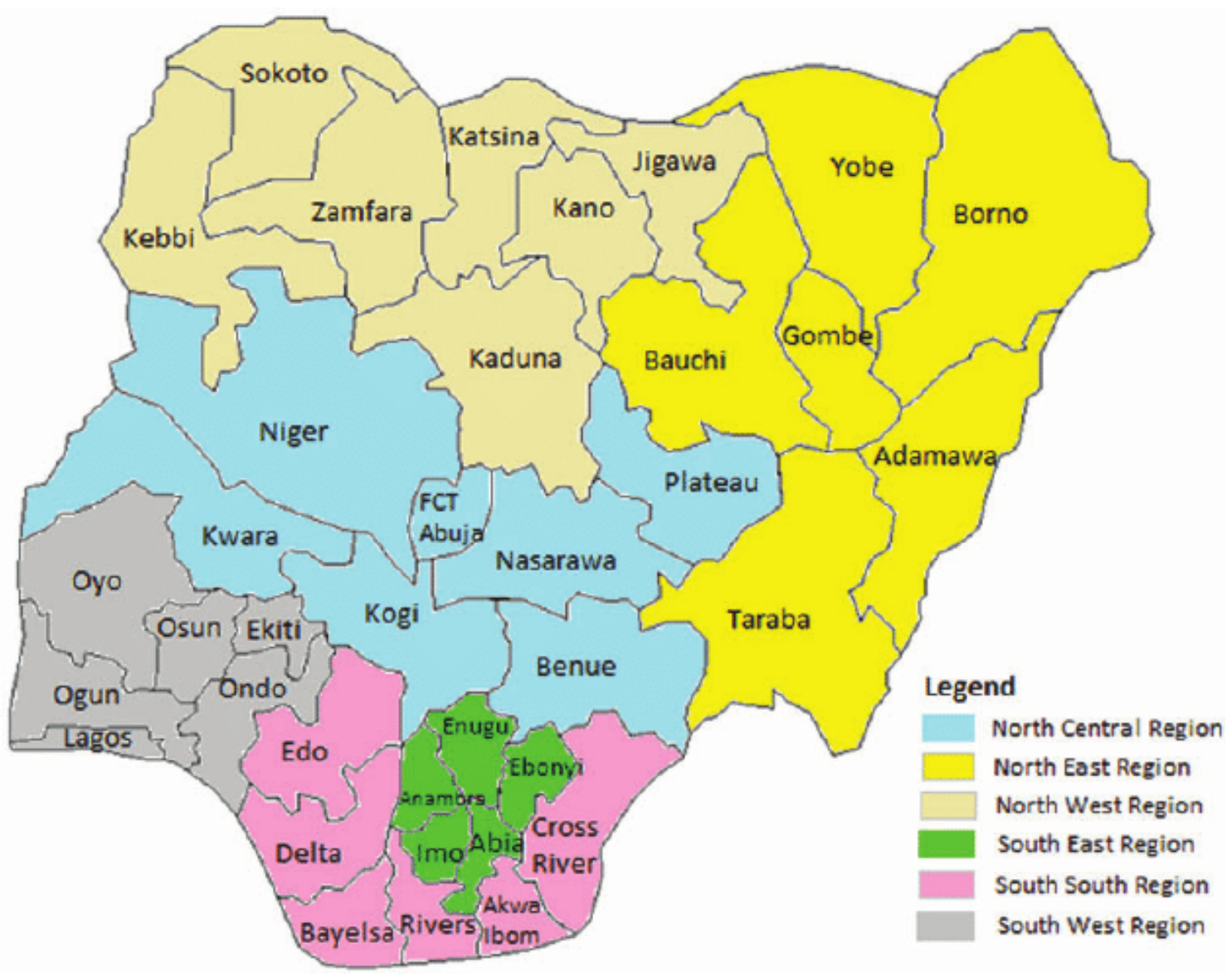

Source: Google map, 2019

Figure 1. Administrative Map of Nigeria 
Nigeria is the largest country in West Africa and has an area of $923,768 \mathrm{~km}^{2}$ of which its land area is about $910,768 \mathrm{~km}^{2}$ while $13,000 \mathrm{~km}^{2}$ is water. It has a coastal line of about $853 \mathrm{~km}^{2}[5,7]$. Nigeria is mainly an agrarian society until five decades ago when oil was discovered. Agriculture was the principal foreign exchange earner for the country. Even now that the economy is largely dominated by oil and gas sector, more than $60 \%$ of the work force is employed in the agricultural sector largely dominated by non-commercial farming [7]. This indicates that soil and land resources are very important in this discourse as land remains invaluable resources and that the information acquired from it would go a long way to ensure sustainability in all developments that are attached to land resources in the country. Sustainable development affects the land as a resource [6], land use in any environment and the major land use in Nigeria which calls for urgent attention is that of housing, agriculture, roads, and commercials, rural and urban development. These include roads, the buildings and other conflicts that may arise as a result of land use. The demand for arable crops, grazing lands, forestry, wildlife, tourism, commercial development and water resources are greater than the carrying capacity of the available land resources.

\subsection{Digital Mapping and Land Information System (LIS)}

The end products of digital mapping have capabilities for embedding attribute data in GIS environment. Execution of digital mapping is an expensive venture in the short-term, but becomes more cost effective on the long run due to easy updating of maps, easy retrieval and duplication of maps, and above all, adaptability of a single digital mapping of area coverage into several or multipurpose usage. Digital maps are useful and can be applied to suit various purposes, an example of such application is the Property Database Management System for revenue generation in any state in Nigeria.

In any sustainable development, lands and land uses are very essential. The information on land and its uses are got from Land Information System (LIS). LIS is a geographic information system (GIS) for cadastral and land-use mapping, typically consisting of accurate, current and reliable land record cadastre and associated attributes [16]. Information is power! Therefore, reliable information on land use that will make the development a continuous one in an environment is of paramount importance and this calls for surveying and mapping exercise for decision making. Digital mapping has its application in the following areas such as housing, roads, parks and garden, recreation and tourism, transportation, land fill sites, fuel stations and the minimum set back expected for sustainability are got from land information system which are carried out through proper surveying and mapping $[13,11]$.

\subsection{Development Regulations in Nigeria}

The development regulation (control) in Nigeria is categorized into two namely: the Institutional and the legal/public policies provision for setbacks in Nigeria.

\subsection{Institutional Framework for Development Control in Nigeria}

Urban development functions are distributed among three bodies: the Planning Authority, the Urban Council and the Health Authority [10]. Each is controlled by a separate state ministry and each has separate regulations (in many instances, conflicting ones) to operate. The planning Authority operates the town and country planning law, the municipal council operates the building regulations and by-laws, and the health authority operates the health regulations. This fragmentation and overlapping responsibilities breed disorder and confusion in city development management. Hence there must be proper cooperation among the ministries/agencies/parastatals involved in enforcing development management laws.

'Land Use Development Controls is one of the powers exercised by planning authorities over developments within their jurisdiction [2]. It is only the planning authorities that are vested with the power under a country's planning laws. Such power is exercised through a collection of interrelated para-legal, administrative techniques and policy instruments designed to safeguard, regulate, conserve and disburse land to enhance the interest and well-being of the overall community. The principal goals of development control include the attainment of a balanced harmonious growth, the assurance of a suitable environmental quality, the prevention of the overloading of infrastructure, the protection of the rights of individuals as well as establishment of acceptable measures and control ensure standard of living.

More also, developmental control ensures that developments comply with survey plans prepared, such control efforts are to minimize the potentials for inconsistent uses of neighbouring parcels of land. The purpose for the developmental control includes the followings:

i) It ensures that all the developers conform to the laid down provisions of approved plans and scheme. This is applicable in areas where developments have not significantly outpaced such approved plans and schemes.

ii) Concerted efforts are directed at improving living conditions in unplanned areas to check further spread of unplanned environments. This is the case where developments have taken place largely without effective physical development plans. Under this condition further development and re-developments are strictly monitored to ensure that the health of the community is not jeopardized. 
iii) Development controls are needed to allow for and ensure greater predictability in urban growth and development so as to make for more adequate provision for public services and also reduce overloading of infrastructure.

iv) Separation of some land use activities such as industrial and residential are necessary as a means of protecting public health, safety and welfare.

v) There are economic considerations such as the need to stabilize land uses as well as stabilize and protect property values.

\subsection{Legal/ Public Policy Provisions for Setbacks in Nigeria}

Town and Country Planning Ordinance in 1946 was the first bold move to institutionalize physical planning in Nigeria. The aim of the ordinance was for re-planning, improvement and development of different parts of the country through planning schemes initiated by the planning authorities. The 1946 town and country planning ordinance have many remarkable features including one that actually touched on the control of development and which made the planning authorities to secure the control of development through the preparation of planning schemes made by the planning authorities. The ordinance states the scope and contents of schemes for the purpose of prohibiting and regulating the development and use of land which, in the actual fact, bothers on development control. In this ordinance the schemes provides for the reservation of land for roads and establishment of public rights of ways, regulating the line, width ,level, construction and general dimensions and character of roads whether new or existing .Also a scheme regulates and controls the size, height ,spacing and building line, the location of buildings .The scheme again limits the number of buildings or the number of buildings of a specified class which may be constructed ,erected or made on, in or under (as applied to Layout Survey) any area. It also provides for the reservation of sites for places of religious worship, schools and buildings and for public services, open spaces and burial grounds. The scheme is also to facilitate the construction of works in relation to lighting, water supply, sewage, drainage and refuse disposal or other public utility services, establishment, extension or improvement of systems of transport whether by land, water or air.

\subsection{Method of Data Collection}

Data for the research was collected from both primary and secondary sources. The primary data was obtained using field survey. The physical measurement of the area in question was done on the categories of application of digital maps and the types of setbacks to buildings, roads, railway lines, water bodies and to educational facilities in Nigeria. 300 copies of questionnaire were administered on developmental controls of the setbacks on land use form in different localities bearing in mind the minimum standard set for the different developments in each locality. The attribute data were tested using chi-square method to determine the relationship between the measured values and the expected value from the field. The study revealed that majority of the result gathered showed their level of non-compliance.

The secondary data were collected from the internet and from the Ministry of Lands, Housing and Urban Development as seen in tables 1 and 2 
Table 1. Some Sectoral Usage/ Application of Digital Mapping Information

\begin{tabular}{|c|c|c|}
\hline Sectoral Application & Typical Usage & $\begin{array}{l}\text { Digital Geodata } \\
\text { Required* }\end{array}$ \\
\hline Finance & Revenue Generation, Customs and Immigration, Tax Administration & LM \\
\hline Local Government & $\begin{array}{l}\text { Taxation, Land use, New Town development, Utility Services management and } \\
\text { monitoring, Tenement rates, Licences, Boundary Administration, Road } \\
\text { Maintenance. }\end{array}$ & CM, LM \\
\hline Agriculture & $\begin{array}{l}\text { Cultivation Inventory, Vegetation Cover, Soil Study, River, Dams and Irrigation, } \\
\text { Land Use, Crop Yield Monitoring and Marine Resources }\end{array}$ & LM, TM \\
\hline Forestry & $\begin{array}{l}\text { Forest Mapping, Forest Inventory, Change Detection, Forest Development, } \\
\text { Timber Production for Export and Domestic Uses }\end{array}$ & TM, LM \\
\hline Political/Administration & $\begin{array}{l}\text { International, Interstate and Local Government Area boundary demarcation, } \\
\text { Constituency delimitation }\end{array}$ & LM \\
\hline Transport and Aviation & $\begin{array}{l}\text { Roads and Airport Runway design, Aeronautic charts for navigation, search and } \\
\text { rescue operation, traffic planning and monitoring, alternative routes planning. }\end{array}$ & LM \\
\hline Petroleum Resources & Oil and Gas Exploration, Exploitation, Distribution, Marketing and Monitoring & LM, TM \\
\hline Geology and Soil Minerals & $\begin{array}{l}\text { Photo geology, reconnaissance, soil study, soil mineral exploration, exploitation, } \\
\text { distribution, marketing and monitoring. }\end{array}$ & LM, TM \\
\hline Planning & $\begin{array}{l}\text { Urban and Regional Planning, Urban renewal and Change Studies, Feasibility } \\
\text { studies, land use mapping, land administration, land certificate, location of } \\
\text { industries. }\end{array}$ & LM, TM, CM \\
\hline Environment & $\begin{array}{l}\text { Risk Zone Mapping, Environmental Inventory and Monitoring, Desertification, } \\
\text { Flood and Erosion Monitoring, Land degradation, Environmental Impact } \\
\text { Assessment and Coast or River Banks Monitoring }\end{array}$ & LM, TM \\
\hline Security & $\begin{array}{l}\text { Defence, Crime Prevention and Monitoring, Search and Rescue Operations and } \\
\text { Vehicle Tracking. }\end{array}$ & LM \\
\hline Population Census & $\begin{array}{l}\text { Planning, Enumeration Areas Delineation, Demographic Studies and Analysis, } \\
\text { Polling Booths Locations. }\end{array}$ & LM \\
\hline Tourism & Road network maps and streets guides, tourist centres and hotel locations. & LM \\
\hline Health & $\begin{array}{l}\text { Epidemic Location, Prevention and Forecasting, Facilities Planning, } \\
\text { Management and Distribution, Location of Emergency Ambulance Services } \\
\text { Points, Planning Mobile Hospital Routes and Rural Health Management } \\
\text { Planning. }\end{array}$ & LM \\
\hline Education & $\begin{array}{l}\text { Facilities Planning, Instruction/Learning Aids Distribution, Location and } \\
\text { Sighting of Institutions }\end{array}$ & LM \\
\hline Sport Development & Facilities Planning, Development and management & LM \\
\hline Archaeology & Georeferencing of Historical Locations and Research Studies. & LM \\
\hline $\begin{array}{l}\text { Communication } \\
\text { (Telecommunication and } \\
\text { Postal services) }\end{array}$ & $\begin{array}{l}\text { Distribution and Location of communication lines and facilities. Distribution and } \\
\text { location of postal services. Road network services and coverage }\end{array}$ & LM \\
\hline $\begin{array}{l}\text { Electricity and Power } \\
\text { Distribution }\end{array}$ & $\begin{array}{l}\text { Power Distribution network location, Facilities distribution, location and } \\
\text { maintenance, customer location and revenue collection }\end{array}$ & LM \\
\hline Water Corporation & $\begin{array}{l}\text { Facilities distribution and location, pipeline distribution, location and } \\
\text { management, customer enumeration and revenue collection. }\end{array}$ & LM \\
\hline Banking and Insurance & Distribution and location of banks, customer enumeration, facilities maintenance & \\
\hline
\end{tabular}

Source: Adapted from Oluwamotemi,2015

LM: Line Maps: These contain topographical, road, utilities, boundary, administrative layers at various scale

TM: Thematic Maps: These are customized maps for specific purposes. They include Geological, Land Use/ Land Cover, Vegetation, Mineral and Soil Maps at various scales.

CM: Cadastral Maps: These contain Land Parcel Identifier, Ownership, Use and Tenement Rate, Conveyance History. 
Table 2. Minimum Set Backs for Developmental Control in Nigeria.

\begin{tabular}{|l|l|l|}
\hline S/N & Various items & Set Back \\
\hline 1 & Streams, Rivers & $30 \mathrm{~m}$ \\
\hline 2 & Water works. Dam/Water Bodies & $100 \mathrm{~m}$ \\
\hline 3 & Federal Roads (High ways) & $50 \mathrm{~m}$ \\
\hline 4 & State Road (Trunk B) & $30 \mathrm{~m}$ \\
\hline 5 & Local Government Roads & $4.5 \mathrm{~m}$ \\
\hline 6 & High Tension Power line & $45 \mathrm{~m}$ \\
\hline 7 & Medium Tension & $15 \mathrm{~m}$ \\
\hline 8 & Low Tension (Domestic) & $4.5 \mathrm{~m}$ \\
\hline 9 & GSM Cell (Antenna) & $10 \mathrm{~m}$ \\
\hline 10 & Optic Fibre line & $4.5 \mathrm{~m}$ \\
\hline 11 & Main Water Pipe line & $15 \mathrm{~m}$ \\
\hline 12 & Quarry Site & $100 \mathrm{~m}$ \\
\hline 13 & Railway & $30 \mathrm{~m}$ \\
\hline 14 & Gas Pipe line & $30 \mathrm{~m}$ \\
\hline
\end{tabular}

Source: Ministry of Lands, Housing, Urban and Regional Development, Ado-Ekiti (2011)

Table 2 shows the minimum setbacks for developmental control in Nigeria as provided and obtained from the Ministry of Lands, Housing, Urban and Regional Development, Ado-Ekiti. The information provided serves as standard to follow in order to prevent any hazard or unforeseen problems emanating from improper implementation of the land information system provided. This information is applicable to assist different features earmarked as sustainable development and to avert insecurity on land in Nigeria with Ekiti State inclusive. This also would help various government agencies saddled with the responsibilities of enforcing developmental laws to rise up to their responsibilities and do so because 'a stitch in time saves nine'

\subsection{Data information Management (Analysis)}

Data collected are integrated into geospatial data bases. Google imageries data and other attribute data on various developments and setbacks were integrated into the GIS environment to enable the digital maps useful. The software used was Arc GIS 10.3 for the data processing, analysis and generation of maps. In order to make some developments sustainable and ameliorate the possible security threat due to environmental hazards experienced nationwide, the queries about how compliant people are to the issue of setbacks are discussed to further tell the world the significance of surveying and mapping in Nigeria with reference to Ekiti State in particular

\section{Results and Discussion}

\subsection{Results}

\subsubsection{Types of Setbacks for the Developmental Control in Nigeria}

What are various setbacks to different buildings? The result of Chi-square, $X^{2}=46.16$ reveals all the items shown in table3 were not compliant to the laid down rule, and that in any of the layout design, setbacks to building depend on the type of area, that is, Low, Medium and High density area. On low density area where a single building with its boys' quarter is built on an approximately 0.5 hectares of land, this allows enough space to accommodate beautifications, soak away pit, septic tanks and setback for urban agriculture or recreational space. On medium density areas which measures $18 \mathrm{~m}$ by $36 \mathrm{~m}$, setbacks ranging from $3 \mathrm{~m}$ to $6 \mathrm{~m}$ are created from the building lines to the boundary. The building lines should be followed strictly so as to have uniform and aesthetic environment. All these information provided are mapped out and appropriately applied for nations' building.

What about the setback to roads and railway lines? The data collated in table 3 shows the setbacks to new road construction, the existing roads and railway lines as well as the level of compliance as observed on Nigerian roads. The table shows that the setbacks got vary from $6 \mathrm{~m}$ to $45 \mathrm{~m}$ depending on the grade of the roads. For trunk A (Federal roads) it is $45 \mathrm{~m}$ from the site (chain line) to the centre of the road. It is expected that the setbacks be carried out as the law provides in table 2 but when measured, the width of the highways from the field were found to be from $7.5 \mathrm{~m}$ to $7.8 \mathrm{~m}$ which were the offsets measured from the centre of the road to the chain line/ boundary. Within the setback provided, certain features such as drains or drainage pathway between network of roads constructed should have been provided to prevent flooding and water logged area and set out to avoid truncation of the roads due to action of running water or flash flooding as witnessed in most of the road networks. The minimum setbacks between railway line and building is $30 \mathrm{~m}$, the right of ways created on both sides is to accommodate future development, pedestrian movement and to prevent accident. Minimum distances between railway lines and building in rural area is $60 \mathrm{~m}$. Most of the railway lines are not kept tidy and hardly could somebody recognize that they still function in some localities especially in the country lands in Nigeria see the case Offa railway station is getting moribund and seem unsustainable, also the area occupied by the rail ways have made prime loss to agricultural activities in the town. 
Table 3. Features on Road construction and the existing Roads

\begin{tabular}{|c|c|c|c|c|c|c|}
\hline Items & Observed (O) & Expected (E) & $\mathbf{O}-\mathbf{E}$ & $\mathbf{( O - E ) ^ { 2 }}$ & $\mathbf{( \mathbf { O } - \mathbf { E } ) ^ { 2 } / \mathbf { E }}$ & Remark \\
\hline Highways & $20 \mathrm{~m}$ & $50 \mathrm{~m}$ & -30 & 900 & 18 & Non-compliant \\
\hline State & $10 \mathrm{~m}$ & $30 \mathrm{~m}$ & -20 & 400 & 13.33 & Non-compliant \\
\hline Railway & $10 \mathrm{~m}$ & $30 \mathrm{~m}$ & -20 & 400 & 13.33 & Non-compliant \\
\hline Local & $3 \mathrm{~m}$ & $6 \mathrm{~m}$ & -3 & 9 & 0.75 & Non-compliant \\
\hline Layout & $9 \mathrm{~m}$ & $12 \mathrm{~m}$ & -3 & 9 & 0.75 & Non-compliant \\
\hline 5 & 52 & 128 & & 1718 & $\mathrm{X}^{2}=46.16$ & \\
\hline
\end{tabular}

Source: Author's field work,2018

Table 4. Setbacks to Development on the Flood Prone Areas/Riverine areas

\begin{tabular}{|c|c|c|c|c|c|c|}
\hline Items & Observed (O) & Expected (E) & $\mathbf{O}-\mathbf{E}$ & $(\mathrm{O}-\mathrm{E})^{2}$ & $(\mathrm{O}-\mathrm{E})^{2} / \mathrm{E}$ & Remark \\
\hline Streams & $15 \mathrm{~m}$ & $30 \mathrm{~m}$ & -15 & 225 & 7.5 & Non-compliant \\
\hline Rivers & $15 \mathrm{~m}$ & $30 \mathrm{~m}$ & -15 & 225 & 7.5 & Non-compliant \\
\hline Dam/ Waterbodies & $200 \mathrm{~m}$ & $500 \mathrm{~m}$ & -300 & 90000 & 180 & Non-compliant \\
\hline Quarry site & $30 \mathrm{~m}$ & $100 \mathrm{~m}$ & -70 & 4900 & 49 & Non-compliant \\
\hline Market & $9 m$ & $12 \mathrm{~m}$ & -3 & 9 & 0.75 & Non-compliant \\
\hline 5 & 269 & 672 & & 95359 & $X^{2}=253$ & \\
\hline
\end{tabular}

Source: Author's field work, 2018

Which setback is applicable to the stream/river, dam, quarry site and market?

Result in table 4 shows setbacks to bodies of water concerning developments on the flood prone areas and this depends on the type of river. For small streams the minimum setback is $30 \mathrm{~m}$ and in case of Dams the minimum setback is a radius of $500 \mathrm{~m}$ from the dam. Dams such as, Egbe Dam and Ero Dam in Ekiti State, Asa Dam in Kwara State, Kainji Dam and Shiroro Dam in Niger State were sampled to know the level of compliance and how to lessen the security threat to the environment and Nigeria as a nation. This is done to control flood as there may be accident due to pressure exerted by water on the Dam or the rivers may overflow their banks during the rainy season. Minimum distance between ocean and lagoon to building are $150 \mathrm{~m}$ and $75 \mathrm{~m}$ respectively. These are no longer hold in Lekki area because of human possibilism theory- land reclamation system. The table shows that the expected measurement provided depends on the type of water or rivers when inspected and the survey and mapping carried out in some selected places, revealed the level of compliance to the laid down rules. Adegboyega (2006) revealed the state of disrepair of some affected roads in Ado-Ekiti that had gulped a lot of money, this is very dangerous to the environment because of incessant flooding and water logging. Asides this, it has negative impact on the transportation along the major roads, for instance, the recent flooding at Ayemi garage along the
Ado-Iworoko road and Ado-Ikare road all in Ado-Ekiti are facing similar problem and need very urgent intervention from either the federal or state government, the work needs urgent attention and intervention .This could be done through LIS and mapping system.

Explain the setbacks to PHCN, NNPC and other Institutions? The minimum setback between a building and PHCN low tension overhead cable ( $11 \mathrm{kv}$ or $33 \mathrm{kv})$ as in tables 1 and 5 ranges from $4.5 \mathrm{~m}$ to $45 \mathrm{~m}$ based on the capacity of the wire tension. Are these achievable today? No! Investigation reveals that most developments are at variance to the laid down principle which indicates the imminent danger and security threat looming on the people of Nigeria. The level of non-compliance is revealed with result of chi-square computed in table $5 . \mathrm{H}_{0}=$ the null hypothesis that is rejected thus, pave way for alternative $\mathrm{H}_{1}$ as seen above. The setbacks to the highlighted development indicated their level of compliance whether they are or not compliant to the town and country planning law, this constitutes a lot of security threats. Some houses are built under high tension in the form of kiosks and farms. These are dangerous to the environment as well as people concerned in most places observed. These I observed in most states such as Lagos, Oyo, Bauchi and host of other states in Nigeria. Surveying and mapping are the antidote to remove the poisonous venom otherwise people's lives is at risk. 
Table 5. Setbacks to Power line (PHCN) and other Utilities

\begin{tabular}{|c|c|c|c|c|c|c|}
\hline Items & Observed (O) & Expected (E) & $\mathbf{O}-\mathbf{E}$ & $(\mathrm{O}-\mathrm{E})^{2}$ & $(\mathrm{O}-\mathrm{E})^{2} / \mathrm{E}$ & Remark \\
\hline Low Tension & $3 \mathrm{~m}$ & $4.5 \mathrm{~m}$ & -1.5 & 2.25 & 0.500 & Non-compliant \\
\hline Medium Tension & $10 \mathrm{~m}$ & $15 \mathrm{~m}$ & -5 & 25 & 1.666 & Non-compliant \\
\hline High Tension & $15 \mathrm{~m}$ & $45 \mathrm{~m}$ & -30 & 900 & 20 & Non-compliant \\
\hline GSM Mast & $5 \mathrm{~m}$ & $10 \mathrm{~m}$ & -5 & 25 & 2.5 & Non-compliant \\
\hline Water Pipeline & $5 \mathrm{~m}$ & $15 \mathrm{~m}$ & -10 & 100 & 6.666. & Non-compliant \\
\hline Gas Pipeline & $10 \mathrm{~m}$ & $30 \mathrm{~m}$ & -20 & 400 & 13.333 & Non-compliant \\
\hline 6 & 48 & 119.5 & & 1452.25 & $X^{2}=44.665$ & \\
\hline
\end{tabular}

Source: Author’s field work, 2018

\subsection{Discussion}

\subsubsection{Land Information Management for Sustainable Development and National Security in Nigeria}

Sustainable development combines economic, social and environmental objectivist to maximize the present human well-being without damaging the ability of future generations to meet their own needs(17;12).Therefore, for sustainable development and national security to hold in Nigeria, some application of surveying and mapping are applied as panacea to the challenges of national security and sustainable development through Land Information System.

It is always the priority of a state to develop a centralized, fair and efficient land, property and zoning administration system. To achieve these goals, it is imperative to have a secure and efficient information system to keep records of the property in the municipality to enable efficient service delivery to its residents by noting that:

- there is an immediate link to revenue generation due to enhanced property tax collection and value added services.

- $\quad$ the implementation of LIS will give room for use by other service providers such as Banks, insurance companies, utility companies and tourism board.

- $\quad$ implementation time is likely to be shorter than other identified projects

- implementation of the Property Database Management System commencing soonest due to short implementation cycle and delivery timelines.

The system will harmonize customary and statutory land and property laws to help generate incremental revenue to local and national government through formal land and property registration fees, property taxes and utility levies. The information system for Nigeria will address precisely, the delivery of a property tax revenue collection system, zoning of the local government areas (postcode / zip code system), street name register and the State resident's database per household for population census for development to name a few.

"Traditional authorities will be assisted to maintain systematic records of land and property transactions and devise formulae which ensure that poorer members of the community are not made landless when rural lands are converted into urban housing plots"

The formula for dispensing the property tax will be one which will be popular to the people and businesses in Nigeria. The State requires a Property Tax Revenue Collection and Information System. Data such as the tax payers name and address are available in the State but there are no proper calculations for assessing property tax and street names and land locations are not adequately zoned. The focus therefore is on recurrent taxes on land, buildings and other properties where, there are dwellings or businesses. A systematic approach employed in an attempt to setting property taxation along with the relevant international institution involved, that is, the International Association of Assessing Officers (IAAO), Institute for Revenues, Rating and Valuation (IRRV). The expected result of the approach is to set taxes that are fundamentally geared towards an international standard, bearing in mind the socio-economic level of the country. We do not intend to design a system that will cause the populace to revert to human nature of wanting to avoid payment of these taxes. The solution to deliver a Property Tax Revenue Collection is not always a standalone system. It interfaces with most other organisations delivering other directly related system such as the Land Registry, Licences and Fines (11).

\section{Conclusions and Recommendations}

\subsection{Conclusions}

This paper has presented a value proposition to show the enormous importance of surveying and mapping. It looked into the legal and institutional frame work of setbacks and creation of Land Information System (LIS) for states in Nigeria. The sectoral usage/application of digital mapping products were discussed to show that every economic sector in Nigeria thrives better with proper planning using geospatial database for decision 
making. The importance of digital mapping and LIS cannot be over emphasized.

\subsection{Recommendations}

Based on the study, the following are recommended as follows:

- That immediate mapping and Multipurpose Database Creation for states in Nigeria should be the priority of the government to allow sustainable development hold.

- Experts and stakeholders are encouraged to be involved at planning and execution stages of digital mapping.

- There should be establishment of Geodetic Control network for harmonisation of all survey and mapping projects in the country as a necessity before the commencement of mapping work.

- Digital Maps which can be reproduced at different scales (1: 2500, 1: 5000, 1: 10000 and 1: 25000) are recommended for Nigeria.

- Nigerians should benefit from the advancement in technology, and see to the proper implementation of setback guidelines by attracting strict penalties to defaulters. A task force should be set to enforce and monitor compliance in Nigeria for the sake of sustainability.

- There should be capacity building and training of Surveyors. These should be geared towards digital mapping and LIS with focus on sustainable national development and security consciousness in Nigeria.

\section{REFERENCES}

[1] Adegboyega, E.R. (2014) Geospatial Mapping for Environmental Resources Management and Sustainability in Ekiti State. Ph.D Thesis, Submitted to the Department of Geography and Planning Sciences, Faculty of the Social Sciences, Ekiti State University, Ado-Ekiti.

[2] Bobrowsky, P and Couture, $\mathrm{R}$ (2014) Landslide Terminology-Canadian Technical Guidelines and Best Practices related to Landslides: A National Initiative for Loss Reduction, Geological Survey of Canada, Open Files6996, :68

[3] Ekiti State of Nigeria Official Gazette (2011) Ekiti State Urban and Regional Planning and Development Laws No/6 of 2011, Government Printers Ado-Ekiti, Ekiti State.

[4] International Federation of Surveyors (FIG) (2006) The Contribution of Surveying Profession to Disaster Risk Management, a publication of FIG Working Group 8.4.(38).

[5] Iwena, O.A,(2008) Essential Geography for Senior
Secondary School TONAD Publisher: 1-10,55- 60 Ikeja Lagos.

[6] Mitchell, B (1979) Geography And Resource Analysis, Longman Group Limited pp57-61, London.

[7] Nigerian Institution of Surveyors (2013) History and Practice of Surveying and Mapping in Nigeria.

[8] Obateru, O.I (2005) Space Standard for Urban Development Pent House Publications Nigeria: 10.

[9] Okeke,M.,(2013) Sustainable Development: Issues, Strategies and Goals, Zenith Economic Quarterly Publications, 9(2) :2,

[10] Okpala, D.C.I (2009) Urban Development Planning Instruction for Effective Plan Implementation, Journal of Nigeria Institute of Town Planners Vol: XX11(1):88-94.

[11] Oluwamotemi, D.K (2015) Mapping as Panacea to the Bane of National Development, a paper presented at the 1st AGM of NIS Ekiti State Branch, held at the Federal Polytechnic, Ado- Ekiti, November 14.

[12] Sampson, E., (2013) Sustainable Development: Issues, Strategies and Goals, Zenith Economic Quarterly Publications 9(2): 26-29,

[13] Sanni,L(1999) An Introduction to Urban and Regional Planning Land of Nigeria, Obafemi Awolowo University Press Ltd., :49-77, Ile-Ife.

[14] Santra, L.C., (2012) Environmental Science, New Central Book Agency Publishers Limited., London

[15] VanDine, D., (2012) Risk Management-Canadian Technical Guidelines and Best Practices related to Landslides: A National Initiative for Loss Reduction, Geological Survey of Canada, Open Files 6996: 8.

[16] Williamson, I.,Enemark, S. ,Welfare, J., Rajaford, A. (2010). Land Administration for Sustainable Development, ESRI Press Academic, Redland, California.

[17] World Commission on Environment and Development (WCED) (1987) Our Common Future, Oxford University Press. Oxford, 